\section{EFFECT OF DIKETOCORIOLIN B ON ANTIBODY FORMATION}

Sir :

Most antitumor compounds have been known to be immunosuppressive, but in contrast, we found that intraperitoneal injection of diketocoriolin $\mathrm{B}(\mathrm{DKC})^{1)}$ increases the number of antibody-forming cells in mouse spleen.

Female $d d / Y$ mice (5 6 weeks old, weighing $18 \sim 20 \mathrm{~g}$ ) were immunized intravenously with sheep red blood cells (SRBC) and the numbers of antibody forming cells was determined 48 hours thereafter by the hemolytic plaque technique ${ }^{2)}$. Results are shown in terms of average number of plaque forming cells (PFC) per $10^{8}$ spleen cells. One $\mathrm{mg}$ of diketocoriolin $\mathrm{B}$ was dissolved in $0.2 \mathrm{ml}$ of dimethylsulfoxide, then $1.8 \mathrm{ml}$ of saline and a trace of Tween 80 (Wako Pure Chemical Ind. Ltd., Japan) were added. Each $0.2 \mathrm{ml}$ of saline-diluted solution was in jected to mice intraperitoneally.
As shown in Table $1,125 \mathrm{mcg} / \mathrm{mouse}$ of DKC suppressed the primary immune responce. However, 31.2, 10 and $0.01 \mathrm{mcg} /$ mouse of DKC markedly enhanced the response. In contrast with the effective dose in antitumor activity, it is apparent that DKC exhibits a stimulatory effect over a wide range of dosage. As reported previously by TAKeUCHi et al. ${ }^{1}$, the $\mathrm{LD}_{50}$ of DKC by single intraperitoneal injection is $40 \mathrm{mg} /$ $\mathrm{kg}, 0.75 \mathrm{mcg} / \mathrm{ml}$ inhibits growth of cultured YosHida sarcoma cells in vitro, at daily intraperitoneal injection of $12.5 \sim 100 \mathrm{mcg} /$ mouse/day for 10 days prolong the survival period of mice intraperitoneally inoculated with cells of $\mathrm{L}-1210$ or carcinoma cells.

We tested the effect of DKC on the secondary immune response. Mice were immunized first with $10^{4}$ or $10^{5} \mathrm{SRBC}$, and $10^{4}$ or $10^{5} \mathrm{SRBC}$ and DKC or DKC alone were injected 7 or 10 days later. Results are shown in Tables 2 and 3 . As shown in Table 2, DKC also enhanced the response to the second in jection of SRBC. Moreover, from 0.6 to $10 \mathrm{mcg}$ of $\mathrm{DKC}$ alone increased

Table 1. Effect of diketocoriolin B on primary immune response

\begin{tabular}{|c|c|c|c|c|c|}
\hline & & & & $\mathrm{PFC} / 10^{8}$ cells & Ratio \\
\hline I & $\begin{array}{cc}\text { SRBC* }^{*} 10^{8} \text { i. v. } \\
" 1 " \\
" 1 " \\
\text { Control } & " 1 \\
& \end{array}$ & $\begin{array}{l}+\mathrm{DKC}^{* *} \\
+\quad " \prime \\
+\quad " \prime\end{array}$ & $\begin{array}{c}125 \text { mcg i. p. } \\
31.2 \mathrm{mcg} " \prime \\
7.8 \mathrm{mcg} " \text { " }\end{array}$ & $\begin{array}{r}447.5 \pm 23.0 \\
144.4 \pm 21.8 \\
838.0 \pm 51.3 \\
1,201.7 \pm 44.8 \\
4.3 \pm 0.2\end{array}$ & $\begin{array}{l}1.00 \\
0.32 \\
1.87 \\
2.69 \\
0.01\end{array}$ \\
\hline II & 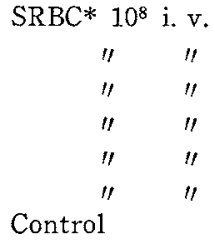 & $\begin{array}{l}+\mathrm{DKC} * * \\
+\quad " \prime \\
+\quad \prime \\
+\quad " \prime \\
+\quad " \prime\end{array}$ & $\begin{array}{l}10 \mathrm{mcg} \\
1 \mathrm{mcg} \\
0.1 \mathrm{mcg} \\
0.01 \mathrm{mcg} \\
0.001 \mathrm{mcg}\end{array}$ & $\begin{array}{r}587.6 \pm 11.4 \\
930.7 \pm 54.8 \\
873.5 \pm 73.2 \\
1,148.3 \pm 72.7 \\
966.5 \pm 10.7 \\
607.5 \pm 41.1 \\
26.5 \pm 2.5\end{array}$ & $\begin{array}{l}1.00 \\
1.58 \\
1.48 \\
1.95 \\
1.65 \\
1.03 \\
0.05\end{array}$ \\
\hline
\end{tabular}

* SRBC $10^{8} / 0.1 \mathrm{ml} /$ mouse ** Each dose of $\mathrm{DKC} / 0.2 \mathrm{ml} /$ mouse

Table 2. Effect of diketocoriolin B on secondary immune response. I

\begin{tabular}{|c|c|c|c|c|c|c|c|c|}
\hline \multicolumn{2}{|c|}{ Primary } & \multicolumn{4}{|c|}{ Secondary* } & $\mathrm{PFC} / 10^{8}$ cells** & \multicolumn{2}{|c|}{ Ratio } \\
\hline \multicolumn{2}{|c|}{ SRBC $10^{5}$ i. v. } & \multicolumn{4}{|c|}{-} & $47.9 \pm$ & - & 1.00 \\
\hline$" 1$ & $\prime \prime$ & \multicolumn{4}{|l|}{ SRBC $10^{5}$ i. v. } & $6,933.5 \pm 311.2$ & 1.00 & - \\
\hline$" 1$ & $\prime \prime$ & \multicolumn{4}{|c|}{ + DKC $10 \mathrm{mcg}$ i. p. } & $12,420.0 \pm 242.5$ & 1.79 & 一 \\
\hline$" 1$ & $\prime \prime$ & - & $+\mathrm{DKC}$ & $10 \mathrm{mcg}$ & $" \prime$ & $197.6 \pm 33.6$ & - & 4.05 \\
\hline$\|$ & $\prime \prime$ & $\longrightarrow$ & $+: 1$ & $2.5 \mathrm{mcg}$ & $" \prime$ & $719.3 \pm$ & 一 & 14.73 \\
\hline \multirow[b]{3}{*}{ Controt } & \multirow[t]{3}{*}{$\prime \prime$} & $-\cdots$ & & $0.6 \mathrm{mcg}$ & $" \prime$ & $197.0 \pm$ & 一 & 4.03 \\
\hline & & - & +11 & $10 \mathrm{mcg}$ & $" \prime$ & $18.2 \pm$ & - & - \\
\hline & & Control & & & & $20.8 \pm$ & - & - \\
\hline
\end{tabular}


Table 3. Effect of diketocoriolin B on secondary immune response. II

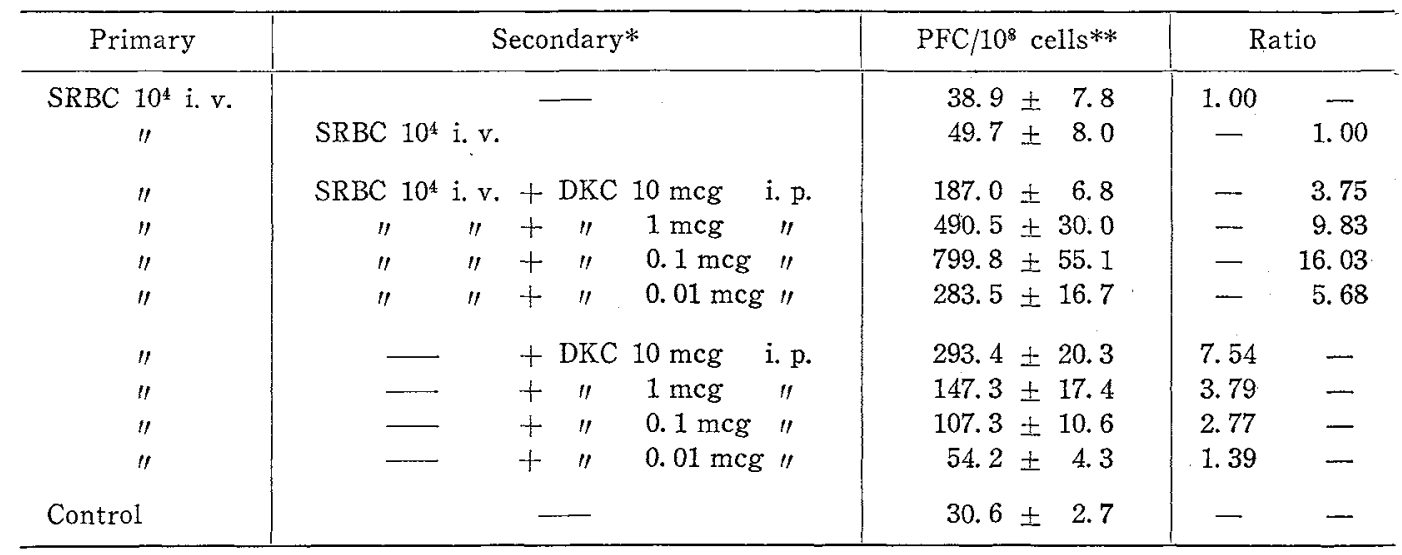

SRBC $10^{4} / 0.1 \mathrm{ml} /$ mouse Each dose of $\mathrm{DKC} / 0.2 \mathrm{ml} / \mathrm{mouse}$

* 10 days after the primary injection ** 48 hours after the secondary injection

the numbers of plaque forming cells. Comparing the numbers of PFC in mice injected with DKC alone to that of primed mice without the second in jection, DKC increased PFC 4 14 times. These observations were confirmed in another experiment, testing the effect on mice immunized with a smaller amount of antigen (Table 3). Mice were first given $10^{4} \mathrm{SRBC}$ and then 10 days later they were injected with $10^{4} \mathrm{SRBC}$ and DKC or $\mathrm{DKC}$ alone. The poor response in primed mice which received a small quantity of antigen was markedly elevated by DKC in dosages as low as $0.1 \sim 1 \mathrm{mcg}$ per mouse.

Kunimoto et al..$^{3)}$ observed that the mode of action of DKC on mammalian cells involves inhibition of $\mathrm{Na}-\mathrm{K}-\mathrm{ATP}$ ase causing efflux of intracellular amino acids and potassium ion and inhibiting their uptake. It is also known that cell membrane effects of chlorpromazine ${ }^{4)}$, phytohemagglutinin ${ }^{5)}$, antilymphocyte serum ${ }^{6)}$ and $\mathrm{Ca}^{++}$ion ${ }^{7)}$ alter antibody forming abilities. The mechanism of such action is however not clear. The mechanism of action of $\mathrm{DKC}$ to increase antibody forming cells is now under study.

\section{Masaaki Ishizuka Hironobu Irnuma Tomio Takeuchi Hamao Umezawa}

Institute of Microbial Chemistry, Shinagawa-ku, Tokyo, Japan

\section{References}

1) Takeughi, T.; S. Takahashi, H. Irmuna \& H. UMEZAWA : Diketocoriolin B, an active derivative of coriolin B produced by Coriolus consors. J. Antibiotics $24: 631 \sim 635,1971$

2) Jerne, N. K.; A. A. Nordin \& C. Henry : The agar plaque technique for recognizing antibody-producing cells. Cell-bound Antibodies. B. Amos and H. Koprowski ed. pp. 109 122, Wister Institute Press, Philadelphia, 1963

3) Kunimoto, T.; M. Hori \& H. Umezawa: Mechanism of action of diketocoriolin B. (to be published)

4) Braun, W. \& M. Nakano: The role of cell breakdown products in the stimulation of immune responses. Symp. Series Immunobiol. Standard. 6: 227 234, Karger, New York, 1967

5) Spreafico, F. \& E. M. Lerner, II : Suppression of the primary and secondary immune response of the mouse by phytohemagglutinin. J. Immunol. $98: 407 \sim 416,1967$

6) YaJima, Y. \& W. BraUn: Non-specific triggering of antibody production by poly- $A$ and poly- $U$ in the presence of lymphocyte serum. Fed. Proc. $28: 431,1969$

7) Braun, W. ; M. . Ishizuka \& P. Sereman : Suppression and enhancement of antibody formation by alteration of $\mathrm{Ca}^{2+}$ levels. Nature $226: 945 \sim 946,1970$ 